\title{
Seasonal distributions of the photosynthesizing ciliates Laboea strobila and Myrionecta rubra (= Mesodinium rubrum) in an estuary of the Gulf of Maine
}

\author{
Robert W. Sanders* \\ Academy of Natural Sciences, 1900 Franklin Parkway, Philadelphia, Pennsylvania 19103, USA
}

\begin{abstract}
The mixotrophic ciliate Laboea strobila was present year-round in the surface waters of the Damariscotta estuary, Maine, USA. In contrast, the abundance of the autotrophic ciliate Myrionecta rubra showed a strong seasonality and was absent during most of the summer and autumn. Nonloricate species usually dominated ciliate abundance and biomass, but tintinnids were occasionally dominant. $L$. strobila constituted up to $15 \%$ of the total ciliate biomass (including $M$. rubra) while $M$. rubra biomass exceeded the combined biomass of all other ciliates on several dates. The maximum biomass observed for $M$. rubra was ca $35 \mu \mathrm{g} \mathrm{Cl}^{-1}$ When $M$. rubra was present, its estimated contribution to primary production was usually greater than that of $L$. strobila. Up to $23 \%$ of total community photosynthesis was attributed to these 2 ciliates even though red water blooms of $M$. rubra were not observed.
\end{abstract}

KEY WORDS: Ciliates $\cdot$ Mixotrophy $\cdot$ Laboea $\cdot$ Myrionecta $\cdot$ Primary production

\section{INTRODUCTION}

The presence of chloroplasts in marine ciliates has been documented numerous times since their incidence was first described by Lohmann (1908). Myrionecta rubra (= Mesodinium rubrum) is the most widely known of the photosynthetic marine ciliates due to its historically recorded occurrences as a red tide organism. $M$. rubra contains a reduced endosymbiotic cryptomonad, does not ingest particulate matter, and is generally acknowledged as an obligate phototroph (Taylor et al. 1971, Smith \& Barber 1979, Crawford 1989). Laboea strobila, like several other species in the Strombididae, retain photosynthetically functional plastids from ingested algal cells. These ciliates require algal food as a source of plastids and other nutritional factors (Stoecker et al. 1987, 1988).

\footnotetext{
•E-mail: rsanders@say.acnatsci.org
}

Both Laboea strobila and Myrionecta rubra have world-wide distribution in coastal waters (Taylor et al. 1971, Lindholm 1985, Stoecker et al. 1987, Bernard \& Rassoulzadegan 1994). Plastid-retaining species (mixotrophs), including $L$. strobila, can constitute a substantial fraction of the ciliates in some coastal and open ocean waters (Stoecker et al. 1987, Putt 1990, Sime-Ngando et al. 1992). Relatively little is yet known, however, about the abundances of mixotrophic ciliates or their contribution to community photosynthesis. Likewise, the role that non-bloom occurrences of $M$. rubra play in community primary production has received little attention. This is despite reports of exceptionally high chlorophyll a concentrations and primary production rates during red water events caused by $M$. rubra (Lindholm 1985, Crawford 1989).

Recently, single cell isolation techniques showed that maximum photosynthetic rates $\left(P_{\max }\right)$ for Laboea strobila and Myrionecta rubra were in the range of those for phytoplankton (Stoecker et al. 1988, 1991). 
Single cell determinations of photosynthetic rates can be combined with abundance or biomass information to estimate the total primary production of the ciliate community (Stoecker et al. 1989). This study investigates the seasonal distribution of $L$. strobila and $M$. rubra in the Damariscotta estuary, Maine, USA, and uses literature-derived photosynthetic rates to calculate the potential contribution of these 2 ciliates to the total primary production.

\section{METHODS}

Three sampling stations were located at approximately $10 \mathrm{~km}$ intervals along the axis of the Damariscotta estuary $\left(43^{\circ} 56^{\prime} \mathrm{N}, 69^{\circ} 35^{\prime} \mathrm{W}\right)$. These correspond to Stns 1, 2 and 3 (from the mouth toward the head of the estuary) in Sanders (1987). Water samples were collected from just below the surface using a 4.51 Van Dorn bottle. Two Van Dorn casts were combined and a 3.51 subsample was preserved with acidic Lugol's iodine (1\% final concentration). Samples were concentrated for Utermöhl counts of ciliates using 3 sequential settling steps of 72 h duration each. From 70 to $90 \%$ of the remaining sample volume was removed by aspiration at each step for a final concentration factor of approximately 500 . The total number of ciliates enumerated per subsample ranged from 100 to $>2100$; replicate counts typically varied by 5 to $15 \%$. Ciliate biovolumes were calculated from length and width measurements by assuming cells conformed to common geometric shapes. Biomass was estimated using a volume-to-carbon conversion factor of $0.19 \mathrm{pg} \mathrm{C} \mu \mathrm{m}^{-3}$ for cells preserved with Lugol's iodine (Putt \& Stoecker 1989).
Primary production was determined monthly (September 1981 through March 1982) from the incorporation of ${ }^{14} \mathrm{C}-\mathrm{NaHCO}_{3}$ (Strickland \& Parsons 1972). Surface water was incubated for $3 \mathrm{~h}$ in $300 \mathrm{ml} B O D$ bottles (3 light bottles, 1 dark) under 'cool-white' fluorescent light (ca $100 \mu \mathrm{E} \mathrm{m}^{-2} \mathrm{~s}^{-1}$ ). Temperature was maintained with flowing water to within $2^{\circ} \mathrm{C}$ of the surface water. Radioactivity was measured using liquid scintillation counting. In order to estimate the contributions of the ciliates Laboea strobila and Myrionecta rubra to community photosynthesis, literature-based rates determined for isolated cells incubated at an irradiance of $100 \mu \mathrm{E} \mathrm{m} \mathrm{m}^{-2} \mathrm{~s}^{-1}$ were multiplied by their abundance (Stoecker et al. 1989). Rates of 85 and $465 \mathrm{pg} C$ fixed ciliate $^{-1} \mathrm{~h}^{-1}$ were used for M. rubra and L. strobila, respectively (Stoecker et al. 1989).

\section{RESULTS AND DISCUSSION}

Laboea strobila was detected at one or more stations on every sampling date during the study. It was observed at Stn 2 (mid-estuary) on all sampling dates except one, but had more sporadic occurrences at the mouth and head of the estuary (Table 1). The maximum abundance of this species in the Damariscotta was 775 cells $l^{-1}\left(8.23 \mu \mathrm{g} \mathrm{Cl}^{-1}\right)$ at Stn 2 during September. L. strobila generally did not exceed $1.5 \%$ of the total ciliate biomass (Fig. 1). The biomass of L. strobila was greater than that of tintinnid ciliates on several occasions (Fig. 1), but even when the biomass of the obligate phototroph Myrionecta rubra was excluded, it did not exceed $20 \%$ of the total ciliate biomass. The abundances of $L$. strobila in this study are similar to those observed in July on Georges Bank and the Gulf

Table 1. Abundances (no. $1^{-1}$ ) of Laboea strobila, Myrionecta rubra and other ciliates in the Damariscotta estuary, Maine, USA. Dashes indicate species not observed. nd: no data. Dates given as Month/Day

\begin{tabular}{|c|c|c|c|c|c|c|c|c|c|c|c|c|c|c|c|}
\hline & \multirow{2}{*}{$5 / 7$} & \multirow[b]{2}{*}{$6 / 17$} & \multirow[b]{2}{*}{$7 / 9$} & \multirow[b]{2}{*}{$8 / 11$} & -1981 & \multirow[b]{2}{*}{$9 / 15$} & \multirow[b]{2}{*}{$10 / 13$} & \multirow[b]{2}{*}{$11 / 17$} & \multirow[b]{2}{*}{$12 / 10$} & \multirow[b]{2}{*}{$1 / 12$} & \multirow[b]{2}{*}{$2 / 11$} & \multirow{2}{*}{$\begin{array}{c}-19 \\
3 / 4\end{array}$} & \multirow[b]{2}{*}{$3 / 25$} & \multirow[b]{2}{*}{$4 / 15$} & \multirow{2}{*}{$\overline{5 / 13}$} \\
\hline & & & & & $8 / 31$ & & & & & & & & & & \\
\hline \multicolumn{16}{|l|}{ Stn 1} \\
\hline L. strobila & 40 & 2 & 4 & - & 20 & - & - & - & 15 & 55 & 10 & 10 & 120 & 30 & 90 \\
\hline M. rubra & - & - & - & - & nd & - & - & - & 690 & 2150 & 4100 & 4140 & 4060 & 575 & 9750 \\
\hline Other ciliates & 4500 & 1160 & 2100 & 130 & nd & 300 & 10200 & 345 & 1050 & 1820 & 2100 & 3430 & 7330 & 6740 & 13000 \\
\hline \multicolumn{16}{|l|}{ Stn 2} \\
\hline L. strobila & 30 & 5 & - & 1 & 60 & 775 & 30 & 2 & 50 & 10 & 5 & 25 & 20 & 20 & 100 \\
\hline M. rubra & - & - & - & - & 85 & 700 & - & - & 5740 & 3720 & 2900 & 4330 & 5170 & 4800 & 37000 \\
\hline Other cillates & 12130 & 3730 & 1170 & 4880 & 5820 & 29400 & 1750 & 495 & 4360 & 2770 & 2780 & 6110 & 8140 & 20200 & 18900 \\
\hline \multicolumn{16}{|l|}{$\operatorname{Stn} 3$} \\
\hline L. strobila & 5 & 90 & 1 & 1 & 3 & 15 & 6 & 4 & - & 7 & - & - & - & - & 375 \\
\hline M. rubra & - & - & - & - & nd & 275 & 50 & - & 2640 & 91.0 & 110 & 1780 & 510 & 11620 & 17250 \\
\hline Other ciliates & 18280 & 4400 & 8960 & 9245 & nd & 8925 & 6300 & 635 & 13900 & 875 & 420 & 9650 & 3335 & 35740 & 8690 \\
\hline
\end{tabular}


STATION 1

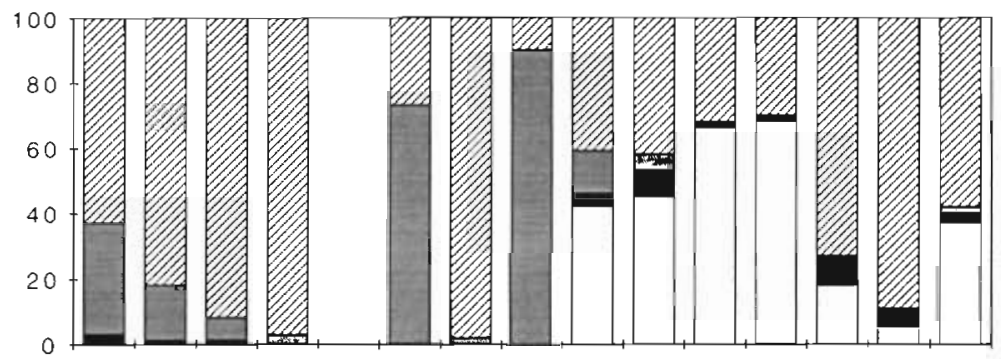

STATION 2

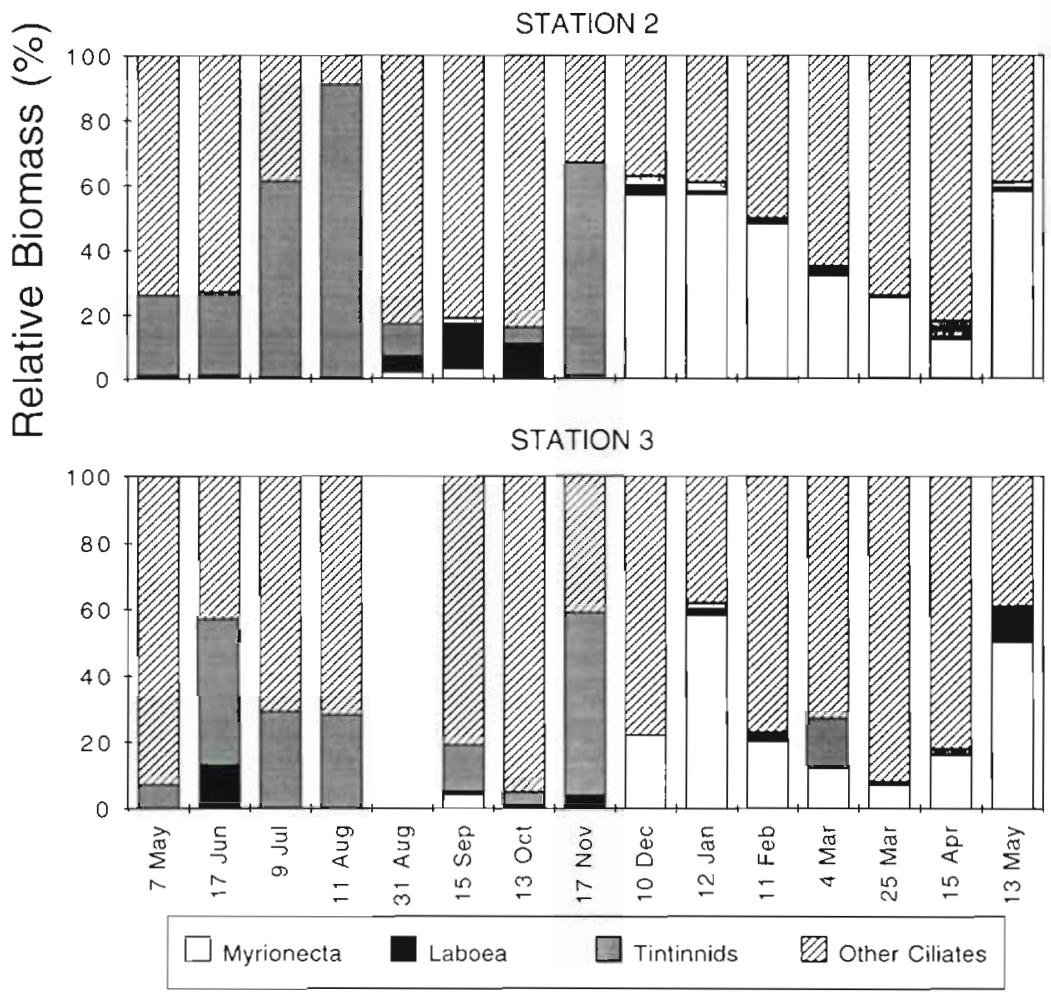

Fig. 1. Relative biomass of the autotrophic clliate Myrionecta rubrum, the mixotrophic ciliate Laboea strobila, other non-loricate ciliates, and tintinnid ciliates in the Damariscotta estuary, Maine, USA

of Maine, and in July-August in the Iceland, Greenland and Barents Seas (Stoecker et al. 1989, Putt 1990). In Long Island Sound, USA, L. strobila was observed on 6 of 7 days in the spring and early summer and exceeded 1000 cells $\mathrm{I}^{-1}$ at some depths during midJune (McManus \& Fuhrman 1986). McManus \& Fuhrman (1986) found that the occurrence of $L$. strobila in Long Island Sound was coupled with that of $M$. rubra. This was not the case during seasonal studies in the Damariscotta estuary or in the Mediterranean Sea (Table 1; Bernard \& Rassoulzadegan 1994).

In contrast to Laboea strobila, the distribution of Myrionecta rubra had a strong seasonality in the Damariscotta estuary. M. rubra was present at all stations between December and April, and generally absent in June through November (Table 1, Fig. 1). This agrees generally with the observations of Montagnes \& Lynn (1989) who observed M. rubra throughout the year around the Isle of Shoals, Maine, but noted very low abundances during the summer and fall. In contrast, biomass peaks and/or red water due to $M$. rubra were observed during the summer in the Mediterranean Sea and in Southampton Water, UK (Kifle \& Purdie 1993. Bernard \& Rassoulzadegan 1994). Although $M$. rubra biomass in the Damariscotta estuary often exceeded that of the phagotrophic ciliates (Fig. 1), M. rubra populations in the Damariscotta estuary never approached the bloom conditions that produce red water phenomena; more than $200000 \mathrm{M}$. rubra cells $\mathrm{l}^{-1}$ are required to give seawater a detectable red coloration (McAlice 1968). Red water conditions due to $M$. rubra, including late summer and early fall blooms, have been reported in close geographical proximity to the Damariscotta estuary, and may even be regularly occurring events in the coastal waters of Maine (Powers 1932, McAlice 1968, White et al. 1977). It is likely, however, that $M$. rubra red water is localized spatially and/or temporally (White et al. 1977, Montagnes \& Lynn 1989).

The factors that regulate abundances of phototrophic ciliates are not well known. Light is obviously a requirement for these autotrophic and mixotrophic ciliates, and Myrionecta rubra and Laboea strobila will often accumulate near the surface at light levels that are apparently optimum for photosynthesis (Smith \& Barber 1979, McManus \& Fuhrman 1986, Stoecker et al. 1988). But turbulence can modify both lateral and vertical aggregations (Crawford 1989). Because vertical stability of the water column is likely an important factor allowing $M$. rubra to reach very high abundances, turbulence may have reduced the probability of observing red water in the Damariscotta estuary. Differences in abundances of both $M$. rubra and $L$. strobila, as well as tintinnids, were generally negligible when samples from the surface, $7 \mathrm{~m}$ and near-bottom (22 $\mathrm{m}$ ) were compared at Stn 2 (results not shown). Tidal mixing is strong the Damariscotta, especially in this section of the estuary 
(McAlice 1977), and undoubtedly contributed to the vertically well-dispersed populations.

Relatively high nutrient concentrations may be required to sustain blooms of Myrionecta rubra (Smith \& Barber 1979, Lindholm 1985). Levels of $\mathrm{NO}_{2}+\mathrm{NO}_{3}$ in the Damariscotta tend to be highest in the winter and early spring (McAlice 1979, Revelante \& Gilmartin 1987) when $M$. rubra abundances also were greatest (Table 1). Temperature could also affect abundances of photosynthetic ciliates. $M$. rubra has been reported in a wide range of temperatures. However, maximum numbers of $M$. rubra tend to be associated with temperatures above, but close to, $15^{\circ} \mathrm{C}$ (Taylor et al. 1971). In the Damariscotta, temperatures exceeded $15^{\circ} \mathrm{C}$ only between June and October (Sanders 1987). Thus, optimum temperatures and the high nutrient levels needed to support blooms of $M$. rubra may not have occurred simultaneously on a frequent basis in this estuary. The direct importance of dissolved nutrients and temperature to Laboea strobila and other mixotrophic species has not been studied.

Both top-down and bottom-up predator-prey interactions may also play a role in population control of photosynthetic ciliates. Since ciliates are ingested by a variety of aquatic organisms (Sanders \& Wickham 1993), predation (top-down control) can reduce abundances. The presence of suitable amounts and types of prey/plastids (bottom-up control) could also limit some mixotrophic ciliates (i.e. those that retain ingested plastids). It is likely that multiple environmental factors, including light intensity, turbulence, temperature, nutrient level, and predator-prey interactions, act together to encourage or limit blooms of photosynthetic ciliates.

Both Myrionecta rubra and Laboea strobila can account for measurable contributions to community photosynthesis. The highest rates of community primary production determined during this study were in early spring at Stns 2 and 3 (8.35 and $9.98 \mu \mathrm{g} \mathrm{Cl}^{-1} \mathrm{~h}^{-1}$, respectively). The maximum rate at $\operatorname{Stn} 1\left(6.13 \mu \mathrm{g} \mathrm{Cl}^{-1}\right.$ $\mathrm{h}^{-1}$ ) occurred in September (Table 2). During periods when community photosynthesis was high, $M$. rubra and $L$. strobila generally accounted for only a few percent of the total primary production in the Damariscotta. At Stn 1 in January and Stn 2 in February, however, $\geq 20 \%$ of the community primary production could be attributed to $M$. rubra (Table 2). Photosynthesis by $L$. strobila contributed a very small part of the planktonic primary production. In September when $L$. strobila was most abundant, it was estimated to have fixed $0.36 \mu \mathrm{g} \mathrm{C} \mathrm{l}^{-1} \mathrm{~h}^{-1}$ which represented $6 \%$ of the community photosynthesis (Table 2). By comparison, McManus \& Fuhrman (1986) estimated that $L$. strobila contributed about $2 \%$ of the total photosynthesis dur-

Table 2. Total measured primary production and calculated estimates of primary production for the mixotrophic ciliate Laboea strobila and the photosynthetic ciliate Myrionecta rubra in the Damariscotta estuary, Maine, USA. The percent of total primary production attributed to each ciliate species is listed in parentheses for dates when total primary production was determined

Primary production reported as $\mathrm{ng} \mathrm{C}^{-1} \mathrm{~h}^{-1}$. Dashes indicate species not observed. nd: no data. Dates given as Month/Day

\begin{tabular}{|c|c|c|c|c|c|c|c|c|c|c|c|c|c|}
\hline & \multirow[b]{2}{*}{$5 / 7$} & \multirow[b]{2}{*}{$6 / 17$} & \multirow[b]{2}{*}{$7 / 9$} & \multirow{2}{*}{$\begin{array}{l}-1 \\
8 / 31\end{array}$} & \multirow[b]{2}{*}{$9 / 15$} & \multirow[b]{2}{*}{$10 / 13$} & \multirow[b]{2}{*}{$11 / 17$} & \multirow[b]{2}{*}{$12 / 10$} & \multirow[b]{2}{*}{$1 / 12$} & \multirow[b]{2}{*}{$2 / 11$} & \multirow{2}{*}{$\begin{array}{c}-1.982 \\
3 / 4\end{array}$} & \multirow[b]{2}{*}{$4 / 15$} & \multirow[b]{2}{*}{$5 / 13$} \\
\hline & & & & & & & & & & & & & \\
\hline \multicolumn{14}{|l|}{ Stn 1} \\
\hline Total production & nd & nd & nd & nd & 6700 & 5370 & 2600 & 1690 & 1200 & 1760 & 4000 & nd & nd \\
\hline L. strobila & 19 & $<1$ & $<2$ & - & - & - & - & 7 & $\begin{array}{r}25 \\
(2 \%)\end{array}$ & $\begin{array}{c}5 \\
(<1 \%)\end{array}$ & $\begin{array}{c}5 \\
(<1 \%)\end{array}$ & 14 & 42 \\
\hline M. rubra & - & - & - & nd & - & - & - & $\begin{array}{r}58 \\
(3 \%)\end{array}$ & $\begin{array}{c}182 \\
(15 \%)\end{array}$ & $\begin{array}{c}349 \\
(20 \%)\end{array}$ & $\begin{array}{r}78 \\
(2 \%)\end{array}$ & 49 & 829 \\
\hline \multicolumn{14}{|l|}{$\operatorname{Stn} 2$} \\
\hline Total production & nd & nd & nd & nd & 6130 & 4330 & 3790 & 3720 & 1460 & 2510 & 8350 & nd & nd \\
\hline L. strobila & 13 & 2 & - & 28 & $\begin{array}{r}360 \\
(6 \%)\end{array}$ & $\begin{array}{c}13 \\
(<1 \%)\end{array}$ & $\begin{array}{c}1 \\
(<1 \%)\end{array}$ & $\begin{array}{c}21 \\
(<1 \%)\end{array}$ & $\begin{array}{c}5 \\
(<1 \%)\end{array}$ & $\begin{array}{c}2 \\
(<1 \%)\end{array}$ & $\begin{array}{c}12 \\
(<1 \%)\end{array}$ & 9 & 47 \\
\hline M. rubra & - & - & - & 7 & $\begin{array}{c}60 \\
(<1 \%)\end{array}$ & - & - & $\begin{array}{c}490 \\
(13 \%)\end{array}$ & $\begin{array}{c}316 \\
(22 \%)\end{array}$ & $\begin{array}{c}246 \\
(10 \%)\end{array}$ & $\begin{array}{r}389 \\
(5 \%)\end{array}$ & 407 & 3150 \\
\hline \multicolumn{14}{|l|}{$\operatorname{Stn} 3$} \\
\hline Total production & nd & nd & nd & nd & 1340 & nd & 2400 & 1900 & 1160 & 1700 & 9980 & nd & nd \\
\hline L. strobila & 2 & 42 & $<1$ & 1 & $\begin{array}{c}6 \\
(<1 \%)\end{array}$ & 3 & $\begin{array}{c}2 \\
(<1 \%)\end{array}$ & - & $\begin{array}{c}3 \\
1<1 \%\}\end{array}$ & - & - & 3 & 174 \\
\hline M. rubra & - & - & - & nd & $\begin{array}{c}23 \\
(2 \%)\end{array}$ & 4 & - & $\begin{array}{c}224 \\
(12 \%)\end{array}$ & $\begin{array}{r}77 \\
(7 \%)\end{array}$ & $\begin{array}{c}9 \\
(<1 \%)\end{array}$ & $\begin{array}{r}395 \\
(4 \%)\end{array}$ & 416 & 1470 \\
\hline
\end{tabular}


ing a spring cruise in Long Island Sound. Estimates of non-bloom production of $M$. rubra generally range from $<1 \%$ to ca $10 \%$ of the primary production (Leppänen \& Bruun 1986, Montagnes \& Lynn 1989, Stoecker et al. 1991), but $M$. rubra accounted for $>70 \%$ of the community primary production during one experiment in a small estuary (Stoecker et al. 1991). $L$ strobila and $M$. rubra together accounted for 1 to $7 \%$ of total photosynthesis (up to $>90 \%$ of the photosynthesis by microplankton) at several stations in the Gulf of Maine during July (Stoecker et al. 1989).

The amount of primary production that is attributable to ciliates in the Damariscotta estuary may be greater than the calculations in Table 2 indicate. Other ciliates, in particular several Strombidium spp., are known to sequester chloroplasts and several have substantial photosynthetic rates (Jonsson 1987, Stoecker et al. 1987, Laval-Peuto \& Rassoulzadegan 1988, Putt 1990). Numerous Strombidium were observed in the Damariscotta estuary during this study, but their abundances were not recorded separately as were those of Laboea strobila and Myrionecta rubra. Thus, no estimate of the photosynthetic contribution was possible. However, Stoecker et al. (1989) estimated that L. strobila and $M$. rubra accounted for only about $50 \%$ of the biomass of ciliates with chlorophyll in shallower waters of the Gulf of Maine. Even if there were smaller proportions of these other photosynthetic ciliates in the Damariscotta than in the Gulf of Maine, it is likely that they augmented the photosynthetic contribution of $L$. strobila and $M$. rubra to community primary production.

There are several factors that could affect the estimates of primary production presented here for Laboea strobila and Myrionecta rubra. Light intensity has a major effect on photosynthetic rate, and both higher and lower rates than those used here have been determined for these 2 species (Jonsson 1987, Stoecker et al. 1988, 1989). The rates used to calculate the photosynthesis of the ciliates were chosen to approximate photosynthetic rates expected at the light levels used for measuring total primary production. Thus, actual field rates likely varied from my estimates due to changing light levels, but proportions of total measured primary production attributed to ciliates (Table 2) should not be considerably different. Likewise, low nutrient concentrations could reduce photosynthetic rates in both ciliates and phytoplankton. For $M$. rubra variations in size could affect the estimates of their photosynthetic contribution. The rate used in my calculations (85 pg C cell ${ }^{-1} \mathrm{~h}^{-1}$ ) was for cells 30 to $50 \mu \mathrm{m}$ in length, but smaller $M$. rubra may have a reduced per cell rate at a given light intensity (Stoecker et al. 1991). Two distinct size classes of $M$. rubra have previously been reported to occur either together or in different seasons (Lindholm 1985, Montagnes \& Lynn 1989, Bernard \& Rassoulzadegan 1994), and 2 size classes of $M$. rubra always co-occurred in the Damariscotta samples. Assuming that photosynthetic rate is proportional to biomass, the primary production reported for $M$. rubra is affected substantially (reduced) only for May 1992, when the small size class represented approximately 50 to $60 \%$ of the enumerated cells at all 3 stations.

Smith \& Barber (1979) emphasized that the contribution of Myrionecta rubra blooms to the productivity of coastal ecosystems was greatly underestimated. It is becoming apparent that even if red water phenomena are not observed, $M$. rubra and several species of mixotrophic ciliates frequently are abundant and can make up a large proportion of the ciliate standing stock in coastal waters (Crawford 1989. Stoecker et al. 1989). Thus, the importance of photosynthesis by $M$. rubra and other ciliates during non-bloom periods also has been underestimated. The few determinations of primary production by ciliates during non-bloom conditions indicate that a sizable proportion of community photosynthesis, especially in the microplankton sizefraction favored by zooplankton predators, can sometimes be attributed to these protists. Furthermore, ciliates, including $M$. rubra, are ingested by a variety of zooplankton and shellfish (Lindholm 1985, Sanders \& Wickham 1993), so it is probable that autotrophic and mixotrophic ciliates make an important contribution to coastal food webs. To understand the true role of photosynthetic ciliates in microbial food webs, future studies are needed to determine how they interact with other trophic levels, and how environmental parameters such as light, nutrients, temperature and food affect phototrophy and phagotrophy by these ciliates.

Acknowledgements. I thank M. Gilmartin for the use of previously unpublished results from primary production incubations, and $T$ Sime-Ngando and 4 anonymous reviewers for useful comments on an earlier version of this paper. Partial support was provided by NSF Grant NSF PPM 8011448.

\section{LITERATURE CITED}

Bernard C, Rassoulzadegan F (1994) Seasonal variations of mixotrophic ciliates in the northwest Mediterranean Sea. Mar Ecol Prog Ser 108:295-301

Crawford DW (1989) Mesodinium rubrum: the phytoplankter that wasn't. Mar Ecol Prog Ser 58:161-174

Jonsson PR (1987) Photosynthetic assimilation of inorganic carbon in marine oligotrich ciliates (Ciliophora, Oligotrichina). Mar microb Food Webs 2:55-68

Kifle D, Purdie DA (1993) The seasonal abundance of the phototrophic ciliate Mesodinium rubrum in Southampton Water, England. J Plankton Res 15:823-833

Laval-Peuto M, Rassoulzadegan F (1988) Autofluorescence of marine planktonic Oligotrichina and other ciliates. Hydrobiologia 159:99-110 
Leppänen JM, Bruun JE (1986) The role of pelagic ciliates including the autotrophic Mesodinium rubrum during the spring bloom of 1982 in the open northern Baltic proper. Ophelia (Suppl) 4:147-157

Lindholm T (1985) Mesodinium rubrum - a unique photosynthetic ciliate. Adv aquat Microbiol 3:1-48

Lohmann H (1908) Untersuchung zur Feststellung des vollständigen Gehaltes des Meeres an Plankton. Wiss Meersunters, Kiel 10:129-370

McAlice BJ (1968) An occurrence of ciliate red water in the Gulf of Maine. J Fish Res Bd Can 25:1749-1751

McAlice BJ (1977) A preliminary oceanographic survey of the Damariscotta River estuary, Lincoln County, Maine. Maine Sea Grant Tech Rep TR-13-77, NOAA, Washington, DC

McAlice BJ (1979) Hydrographic and nutrient dataDamariscotta River estuary, Lincoln County, Maine. Maine Sea Grant Tech Rep TR-43-79, NOAA, Washington, DC

McManus GB, Fuhrman JA (1986) Photosynthetic pigments in the ciliate Laboea strobila from Long Island Sound, USA. J Plankton Res 8:317-327

Montagnes DJS, Lynn DH (1989) The annual cycle of Mesodinium rubrum in the waters surrounding the Isle of Shoals, Gulf of Maine. J Plankton Res 11:193-201

Powers PBA (1932) Cyclotrichium muenierisp. nov. (Protozoa, Ciliata); cause of red water in the Gulf of Maine. Biol Bull $63: 74-80$

Putt M (1990) Abundance, chlorophyll content and photosynthetic rates of ciliates in the Nordic Seas during summer. Deep Sea Res 37:1713-1731

Putt M. Stoecker DK (1989) An experimentally determined carbon:volume ratio for marine 'oligotrichous' ciliates from estuarine and coastal waters. Limnol Oceanogr 34: $1097-1103$

Revelante N, Gilmartin M (1987) Seasonal cycle of the ciliated protozoan and micrometazoan biomass in a Gulf of Maine estuary. Estuar coast Shelf Sci 25:581-598

Responsible Subject Editor: F. Rassoulzadegan, Villefranchesur-Mer, France
Sanders RW (1987) Tintinnids and other microzooplankton seasonal distributions and relationships to resources and hydrography in a Maine estuary. J Plankton Res 9:65-77

Sanders RW, Wickham SA (1993) Planktonic protozoa and metazoa: predation, food quality and population control. Mar microb Food Webs 7:197-223

Sime-Ngando T, Juniper K, Vézena A (1992) Ciliated protozoan communities over Cobb Seamount: increase in biomass and spatial patchiness. Mar Ecol Prog Ser 89:37-51

Smith WO Jr, Barber RT (1979) A carbon budget for the autotrophic ciliate Mesodinium rubrum. J Phycol 15: $27-33$

Stoecker DK, Michaels AE, Davis LH (1987) Large proportion of marine planktonic ciliates found to contain functional chloroplasts. Nature 326:790-792

Stoecker DK, Putt M. Davis LH, Michaels AE (1991) Photosynthesis in Mesodinium rubrum: species-specific measurements and comparison to community rates. Mar Ecol Prog Ser 73:245-252

Stoecker DK, Silver MW, Michaels AE, Davis LH (1988) Obligate mixotrophy in Laboea strobila, a ciliate which retains chloroplasts. Mar Biol 99:415-423

Stoecker D, Taniguchi A, Michaels AE (1989) Abundance of autotrophic, mixotrophic and heterotrophic planktonic ciliates in shelf and slope waters. Mar Ecol Prog Ser 50: $241-1.54$

Strickland JDH, Parsons TR (1972) A practical handbook of seawater analysis. Fisheries Research Board of Canada, Ottawa

Taylor FJR, Blackbourn DJ, Blackbourn J (1971) The redwater ciliate Mesodinium rubrum and its incomplete symbionts' a review including new ultrastructural observations. J Fish Res Bd Can 28:391-407

White AW, Sheath RG, Hellebust JA (1977) A red tide caused by the marine ciliate Mesodinium rubrum in Passamaquoddy Bay, including pigment and ultrastructure studies of the endosymbiont. J Fish Res Bd Can 34:413-416

Manuscript first received: June 16, 1995

Revised version accepted: October 31, 1995 